\title{
Maxillary Sinus Cancer TNM Finding v7
}

National Cancer Institute

\section{Source}

National Cancer Institute. Maxillary Sinus Cancer TNM Finding v7. NCI Thesaurus. Code C89093.

A finding about one or more characteristics of maxillary sinus cancer, following the rules of the TNM AJCC V7 classification system. 